\title{
Sleep deprivation and drowsiness of medical residents and medical students
}

\section{Privação do sono e sonolência excessiva em médicos residentes e estudantes de medicina}

Kátia Sheylla Malta Purim'; Ana Tereza Bittencourt Guimarães³; Ana Cláudia Kapp Titski²; Neiva leite².

\begin{abstract}
A B S T R A C T
Objective: to evaluate sleep quality and daytime sleepiness of residents and medical students. Methods: we applied a socio-demographic questionnaire, the Pittsburgh Sleep Quality Index (PSQI) and the Epworth Sleepiness Scale (ESS) to a population of residents and medical students. Results: hundred five residents and 101 undergraduate medical students participated. Residents presented higher mean PSQI

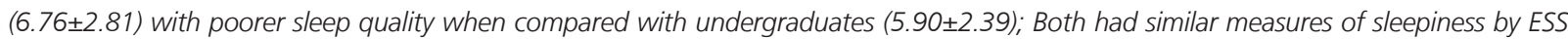
$(p=0.280)$, but residents showed lower duration and lower subjective sleep quality. Conclusion: medical students and residents presented sleep deprivation, indicating the need for preventive actions in the medical area.
\end{abstract}

Keywords: Sleep Wake Disorders. Disorders of Excessive Somnolence. Education, Medical.

\section{INTRODUCTION}

Sleep disturbances are common among night shift Sworkers and may reduce performance, cause increased morbidity, fluctuation in mood, decreased efficacy, increased risk of accidents, and reduced life expectancy ${ }^{1-5}$. Sleep deprivation and the disturbance of its rhythmicity affect the sleep-wake cycle differently from the circadian cycle $e^{1,6-8}$, causing impacts on work capacity ${ }^{9,10}$, such as tiredness, fatigue, irritability, stress, lack of enthusiasm in daily activities, performance decline, cognitive deficit and demotivation ${ }^{1,7}$. Although there is intra-individual and temporal variation in sleep, its disorders are associated, less or more intensely, with behavioral and social relations disorders, decreased attention and concentration, delayed response to stimuli, daytime drowsiness and Burnout Syndrome $8,10,11$.

Research shows that residents have an average of six hours of sleep per night, which is lower than the average adult population, who sleeps from seven to nine hours / night ${ }^{1}$. In addition, there is a reduction in the quality of life indices and elevation of scores on depression and anxiety scales when compared with other doctors and medical students ${ }^{1,9-13}$. A recent study with young physicians on the acute effects of sleep deprivation due to night work demonstrated, through psychomotor tests, a greater latency in the response to simple stimuli, more errors and worse index of perfection, whereas in the Toulouse-Piéron test they found a larger number of omissions and a low concentration index. These conditions may compromise patient care, especially in emergency and trauma surgery services, as well as the own physician'shealth. In view of this, this study aimed to investigate sleep quality and daytime sleepiness of residents comparing with medical students in the final stage of graduation.

\section{METHODS}

We conducted a descriptive research between August and November 2013 with resident physicians and medical students from Curitiba - Paraná, through a project approved by an ethics committee (CEP 307.644).

Inclusion criteria were: adult over 18 years of age, enrolled in a medical residency program or in the

1 - Positivo University Medical School, Curitiba, Paraná State, Brazil. 2 - Federal University of Paraná, Quality of Life Center, Curitiba, Paraná State, Brazil. 3 - Paraná State Western University, Discipline of Biostatistics, Toledo, Paraná State, Brazil. 
medical school internship period, in the internal medicine and surgical clinical sectors, without hierarchical link with the researchers and who agreed to participate in the research through a Signed the Informed Consent Form. We excluded incomplete questionnaires and individuals under treatment for sleep disturbance.

The approach occurred intentionally and through accessibility during the intervals of activities in teaching hospitalsettings. Afteradequateorientation of the participants, we handed the self-application,anonymitypreserving measurement instruments, comprising the following: a) questionnaire for socio-demographic characterization and internet use; b) Pittsburgh Sleep Quality Index (PSQI) and Epworth Sleepiness Scale (ESS), both versions translated into Brazilian Portuguese, tested and validated ${ }^{1}$.

The Pittsburgh Sleep Quality Index (PSQI) has seven components: 1) subjective quality of sleep; 2 ) sleep latency; 3) duration of sleep; 4) habitual sleep efficiency; 5) sleep disorders; 6) use of sleeping pills; 7) daytime sleepiness and daytime disturbances. Each part has specific scores, with 21 points being the maximum score. Scores greater than five indicate poor sleep quality'.

The Epworth Sleepiness Scale (ESS) has eight statements about the tendency to daytime sleepiness in everyday situations, taking into account the individual's way of life in recent weeks. Responses are attributed to a 4-point Likert scale, and the sum of these points results in the final score. Normal scores are up to 10, pathological scores between 11 and 15, and very pathological, between 16 and $24^{1}$.

We analyzed the qualitative variables related to the participant's formation (intern or resident) by means of absolute and relative frequencies, and the quantitative variables by mean and standard deviation. We compared the qualitative variables of personal data and history between the groups using the ChiSquare test for Independence, and in cases of statistical significance, we analyzed pairs of data by means of the Adjusted Residues test. We evaluated the variables 'internet use during the day', 'internet use at night', 'number of subjects doing shifts' and 'number of working subjects' by means of the Chi-square test for K Proportions, followed by the Marascuilo test.

We analyzed the variable 'Pittsburgh Sleep Quality Index' (PSQI) and its respective domains, and the variable 'Epworth Sleepiness Scale' (ESS) as for the data distribution pattern using the Lilliefors test, and the homogeneity of the variances between the interns and residents groups, through the Levene test. We found that the PSQI variable was in congruence with the assumptions of normality and homoscedasticity, so we compared the means of the two groups with the t-test for independent samples. The other variables were not in agreement with those assumptions, so we analyzed themusing the nonparametric MannWhitney-U test. In all tests, we used a significance level of $5 \%$, and performed the analyzes with the software XLStat2013 (Addinsoft, 2013).

\section{RESULTS}

The sample consisted of 206 participants, with 105 resident physicians and 101 undergraduate students working in the specified areas during the study period. We excluded two residents and six interns due to incomplete completion of the questionnaires. Regarding sex, there was a greater amount of female residents (53\%) compared with medical students, who had male prevalence $(51 \%)$. The age group of the residents was concentrated between 25 and 29 years (73\%), and of the interns, between 20 and 24 (67\% $\left.x^{2}=127.5, p<0.05\right)$. Most residents (84\%) and interns were single $(98 \%)$. Only four residents mentioned having children (4\%), and this was not observed among the undergraduates $\left(x^{2}=105.0, p<0.05\right)$.

Most of the medical students came from private institutions (82\%), while among residents the distribution of frequencies was homogeneous between public $(46 \%)$ and private (54\%) institutions $\left(x^{2}=9.287\right.$, $\mathrm{p}<0.05)$. As for internet use for work or study, we found that residents use it both during the day $(98 \%$, $\left.x^{2}=165.048, p<0.05\right)$ and at night $\left(97 \%, x^{2}=151.423\right.$; $\mathrm{p}<0.05)$, with frequencies significantly higher than the interns ( $9 \%$ and $12 \%$, respectively - Table 1). However, 
Table 1. Absolute and relative Frequencies (in parentheses) of history related variables. p-value Chi-square test for Independence*.

\begin{tabular}{|c|c|c|c|c|}
\hline & & Academics & Residents & $p$ \\
\hline \multirow{3}{*}{ Undergraduates institution } & Public & $7^{b}(18 \%)$ & $48^{a}(46 \%)$ & \multirow{3}{*}{0.002} \\
\hline & Private & $32^{\mathrm{a}}(82 \%)$ & $57^{b}(54 \%)$ & \\
\hline & Not informed & 62 & 0 & \\
\hline \multirow{5}{*}{ Residents institution } & Public & $0(0 \%)$ & $58(55 \%)$ & \multirow{5}{*}{ Does not apply } \\
\hline & Private & $0(0 \%)$ & $40(38 \%)$ & \\
\hline & Both & $0(0 \%)$ & $1(1 \%)$ & \\
\hline & Not informed & $0(0 \%)$ & $6(6 \%)$ & \\
\hline & Does not apply & $101(100 \%)$ & $0(0 \%)$ & \\
\hline \multirow{2}{*}{ Use of internet } & Day & $9^{b}(9 \%)$ & $103^{a}(98 \%)$ & $<0.0001$ \\
\hline & Night & $12^{b}(12 \%)$ & $102^{\mathrm{a}}(97 \%)$ & $<0.0001$ \\
\hline Shifts per week & & $\begin{array}{l}1^{\mathrm{b}}(1 \%) \\
\text { (1 shift) }\end{array}$ & $93^{a}(89 \%-2 \pm 1)$ & $<0.0001$ \\
\hline Weekly hours of work & & $\begin{array}{c}1^{\mathrm{b}}(1 \%) \\
(12 \text { hours })\end{array}$ & $\begin{array}{c}104^{\mathrm{a}}(99 \%-77 \pm \\
21)\end{array}$ & $<0.0001$ \\
\hline
\end{tabular}

$a, b$ Indicate statistical difference $(p<0.05)$ between groups of students and residents within each variable category.

on average, residents reported staying on the internet $1.32 \pm 1.21$ hours during the day and $1.60 \pm 1.05$ hours at night, and the academics, $2.11 \pm 1.27$ hours during the day and $1.27 \pm 0.87$ hours at night.

About $89 \%$ of the residents performed weekly shifts $\left(x^{2}=159.168 ; p<0.05\right)$ with an average of $2 \pm 1$ shifts per week; $99 \%$ worked in other places $\left(x^{2}=198.075, p<0.05\right)$, totaling on average $77 \pm 21$ hours of work per week. In this sample, only one intern mentioned paid work (Table 1), although they all carried out student-teaching shifts.

When assessing the total score of the Pittsburgh Sleep Quality Index (PSQI), we found a significant difference between the means of the interns and residents groups $(t=-2.36, p=0.019)$. Residents had a higher mean PSQI index $(6.76 \pm 2.81)$, showing poor sleep quality when compared with the group of medical students (5.90 \pm 2.39 - Table 2$)$.

Among the domains of the PSQI instrument, we observed higher values regarding sleep duration and subjective sleep quality among residents $(p<0.05)$. Residents had lower sleep duration and worse subjective sleep quality when compared with interns, with no differences among the other domains (Table 2).

When evaluating the total score of the Epworth Sleepiness Scale (ESS), there was no significant difference between the values of the interns and residents groups $(U=-4744.5, p=0.280)$. Such a result indicates that interns and residents showed similar measures of drowsiness (Figure 1).

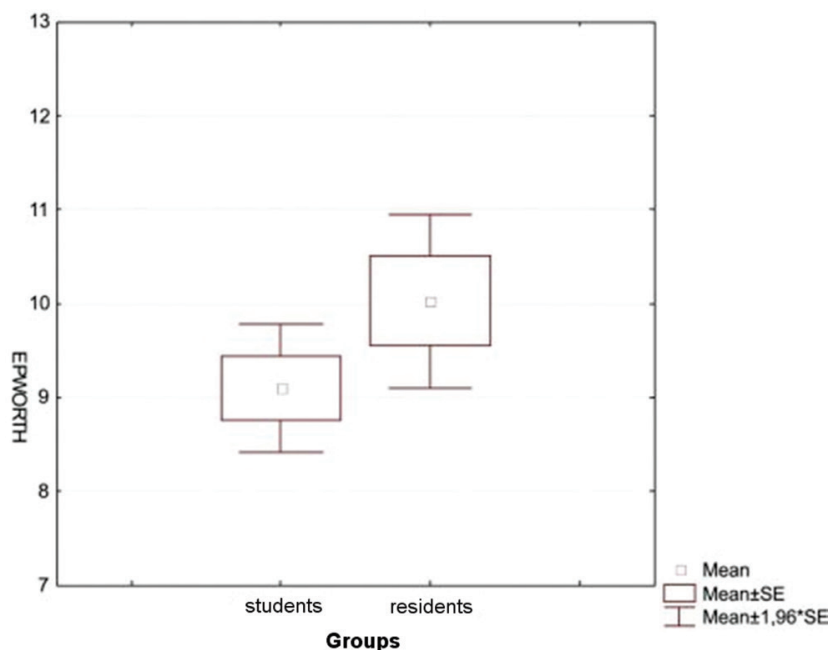

Figure 1. Mean, standard error, and confidence intervals of the Epworth Sleepiness Scale between students and residents. 
Table 2. Averages and standard deviations of the Pittsburgh Sleep Quality Index and its respective domains, and Epworth sleepiness Scale.

\begin{tabular}{lccc}
\hline & Students & Residents & $p$ \\
\hline PSQI * & $5.90 \pm 2.39$ & $6.76 \pm 2.81$ & 0.019 \\
Latency to sleep ** & $1.10 \pm 0.85$ & $1.09 \pm 0.95$ & 0.74 \\
Habitual sleep efficiency ** & $0.31 \pm 0.11$ & $0.45 \pm 0.20$ & 0.37 \\
Sleep duration ** & $0.73 \pm 0.68$ & $1.10 \pm 0.83$ & 0.00 \\
Disorders ** & $1.16 \pm 0.49$ & $1.15 \pm 0.62$ & 0.88 \\
Subjective sleep quality ** & $1.15 \pm 0.66$ & $1.49 \pm 0.84$ & 0.01 \\
Need for sleeping medication ** & $0.21 \pm 0.61$ & $0.70 \pm 0.27$ & 0.83 \\
Daytime dysfunction ** & $1.44 \pm 0.76$ & $1.48 \pm 0.80$ & 0.67 \\
Epworth Sleepiness Scale ** & $9.10 \pm 3.47$ & $10.03 \pm 4.80$ & 0.280 \\
\hline
\end{tabular}

P-value of t-test for independent samples* and Mann-Whitney-U test**.

\section{DISCUSSION}

Sleep disorders affect a considerable number of individuals around the world and are of extreme scientific interest because of their direct and indirect consequences to personal and collective health ${ }^{10,14-16}$. The peculiarities of the requirements of medical training can cause sleep restriction and fragmentation ${ }^{17,18}$, together with individual and socioorganizational factors of work and study. The present sample was composed of young adults, residents and medical students, with an age similar to that of the national literature ${ }^{1,17}$. However, students are younger than residents, are single and without children, and these variables can influence sleep pattern. The lower age range of Brazilian physicians when compared to Portuguese ones ${ }^{6}$ may be justified by methodological and educational differences between the two countries.

Sleep disturbances are frequent in the face of important changes in style and rhythm of life ${ }^{11,19}$. Globalization, access to technology, and a growing tendency to connect in social networks are likely to interfere with sleep hygiene, and in the present sample, it is possible that the time spent on the internet is greater than reported. Doctors and medical students use the internet on a daily basis, and modern hospitals have access to internal protocols via internet platforms, besides the growing popularization of digital mobile technology. In this study, data related to internet use were self-reported and may contain memory bias.

On the other hand, work under on-call shifts, worsened by stress and sleepingdifficulties, causes shorter and non-restingsleep episodes 1,5,10,19. In the present sample, the average weekly working hours of the residents (77 hours) exceeded the recommended one (60 hours), probably due to other external professional ties. These findings concern the potential detrimental effect on training, physical, mental and psychological well-being and the availability of time for leisure, physical activities, social interaction and rest ${ }^{10,13}$.

As for the PSQI, the mean index for residents was 6.76, similar to the results of Cardoso et al. ${ }^{1}$, who found an index of 6.2 for both genders. The recommended limits for the PSQI are values below 5, that is, both studies indicate poor sleep quality among residents.

Moraes et al..$^{20}$ found that medical students in São Paulo took 21.83 minutes to sleep and that they slept, on average, 6.80 hours. Cardoso et al. ${ }^{1}$, using the PSQI instrument, demonstrated that medical students from Goiás took an average of 15.31 minutes to sleep and had an average sleep duration of 6.13 hours. This same study demonstrated statistical significance when comparing the sleep pattern of the residents with the sleep pattern of the first year students. In the present investigation, there was a significant difference between 
averages of interns and residents, showing that residents had worse sleep quality.

A research with 602 Emergency Medicine Residents demonstrated excessive sleepiness in 38\% (ESS 11-16) and severe sleepiness in 7\% (ESS>16) according to the Epworth scale ${ }^{21}$. In Curitiba-PR, an evaluation of 136 residents of various specialties showed pathological

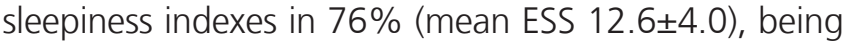
higher in women and in the first year of residence, without significant difference between specialties, but with a decrease in the daytime sleepiness score during the residence training ${ }^{10,13}$. Standards of professional and extraprofessional activities of men and women tend to be different and may interfere with sleep patterns.

Studies on the prevalence of excessive daytime sleepiness in Brazilian medical students also showed inadequate habits and sleep deprivation, with oscillations during the semester and weekends ${ }^{4,22}$. The following ESS scores averages were found among students: 10.72 at the University of Brasilia and 10 at the University of São Paul20. In the present study, the levels of sleepiness detected were similar between residents and medical students, differing from other studies national studies ${ }^{1,20}$, and point to the need to adopt educational strategies aimed at health promotion, including daily and regular physical activity, which can be a resource to improve tolerance to night work.

Among the limitations of this study, it is worth noting that we did analyze variables potentially capable of influencing the occurrence of sleep disorders (such as psychological profile, financial difficulties, preparation for selective processes, family conflicts, food, physical activity and leisure). There was also no stratification according to the variables gender, age, modality and year of medical residency or shifts' characteristics. In addition, we not use Polysomnography, Multiple Sleep Latency Test (MSLT), sleep diary and other resources. Despite these limitations, this research showed important aspects of sleep deprivation in medical training and provokes debate on the relevance of sleep in a society that operates 24 hours, and an increasingly accelerated and connected way, mediated by machines and technologies.
The increase in Burnout syndrome in the medical field ${ }^{5,11}$ may impact sleep quality. Possibly its occurrence, causes and manifestations differ between residents and students. The application of instruments to measure occupational stress could reveal other aspects and topics for further investigation.

Research evaluating anesthesiologists has revealed that sleep and fatigue from night shifts can affect agility, attention, cognitive function, reflexes, and motivation for work ${ }^{23}$. Moreover, surgical environments are generally confined, noisy, busy and stressful places ${ }^{23}$. We should also point out that constant exposure to bright spaces and to the violet blue light emitted by digital devices such as smartphones, computers and tablets can influence the circadian rhythm by affecting the natural release of melatonin, the hormone involved with the sleep-wake cycle ${ }^{24}$.

Thus, it is important to encourage medical students, physicians and residents to learn to healthily manage their living habits and occupational challenges, especially in the surgical areas, to minimize repercussions on the quantity and quality of sleep, as well as on patient care. Practical measures for good sleep hygiene are essential: a) Controlling situations that induce increased arousal - avoid consumption of stimulant medications, caffeine, cigarettes, alcohol, light, temperature and noise in the room, stress, mental work or vigorous exercise close to bedtime; b) Planning the length of sleep and wakefulness - observe regularity at bedtime and waking up time, controlling access and excessive use of digital networks; c) Resting, relaxing and practicing physical activities in the period free of work or shifts, minimizing risks and damages to health and social life; and d) Applying measures that facilitate adaptation to the shift to reduce internal dyssynchronization and sleep disorders related to the circadian rhythm.

In conclusion, in this sample, residents had a higher PSQI mean when compared with medical students, and although ESS sleepiness scores were similar between groups, residents showed lower sleep duration and lower subjective sleep quality. Sleep deprivation requires health promotion actions among residents and medical students. 


\title{
R E S U M O
}

\begin{abstract}
Objetivo: avaliar a qualidade de sono e a sonolência diurna de residentes comparando com estudantes de medicina. Métodos: foram aplicados questionário sociodemográfico, Índice de Qualidade do Sono de Pittsburg (PSQI) e Escala de Sonolência de Epworth (ESE) numa população de residentes e estudantes de medicina. Resultados: participaram 105 residentes e 101 estudantes da graduação médica. Os residentes apresentaram maior média do PSQI $(6,76+2,81)$ com pior qualidade de sono quando comparados aos acadêmicos $(5,90+2,39)$; ambos tiveram medidas semelhantes de sonolência pela ESE $(p=0,280)$, porém os residentes mostraram menor duração e pior qualidade subjetiva de sono. Conclusão: estudantes e residentes apresentaram privação de sono indicando necessidade de ações preventivas na área médica.
\end{abstract}

Descritores: Transtornos do Sono-Vigília. Distúrbios do Sono por Sonolência Excessiva. Educação Médica.

\section{REFERENCES}

1. Cardoso HC, Bueno FCC, Mata JC, Alves APR, Jochims I, Vaz Filho IHR, et al. Avaliação da qualidade do sono em estudantes de medicina. Rev Bras Educ Méd. 2009;33(3):349-55.

2. Ribeiro CRF, Silva YMGP, Oliveira SMC. O Impacto da qualidade do sono na formação médica. Rev Soc Bras Clin Med. 2014;12(1):8-14.

3. Medeiros ALD, Mendes DBF, Lima PF, Araujo J. The relationships between Sleep-Wake Cycle and academic performance in medical students. Biol Rhythm Res. 2003;32(2):263-70.

4. Lima PF, Medeiros ALD, Rolim SAM, Dias Jr SA, Almondes KM, Araújo JF. Changes in sleep habits of medical students according to class starting time: a longitudinal study. Hypnos. 2004;1(1):10-9.

5. Scheffer M, coord. Demografia Médica no Brasil 2015. São Paulo: Departamento de Medicina Preventiva da Faculdade de Medicina da USP, Conselho Regional de Medicina do Estado de São Paulo. Conselho Federal de Medicina; 2015.

6. Sanches I, Teixeira F, Santos JM, Ferreira AJ. Efeitos agudos da privação de sono decorrente do trabalho nocturno em jovens médicos. Acta Med Port. 2015;28(4):457-62.

7. Mahendran R, Subramaniam M, Chan YH. Medical students' behaviour, attitudes and knowledge of sleep medicine. Singapore Med J. 2004;45(12): 587-9.

8. Morphy H, Dunn KM, Lewis M, Boardman HF, Croft PR. Epidemiology of insomnia: a longitudinal study in a UK population. Sleep. 2007;30(3):274-80.

9. Lourenção LG, Moscardini AC, Soler ZA. Saúde e qualidade de vida de médicos residentes. Rev Assoc Med Bras. 2010;56(1):81-91.

10. Asaiag PE, Perotta B, Martins MA, Tempski P. Avaliação da qualidade de vida, sonolência diurna e burnout em médicos residentes. Rev Bras Educ Med. 2010;34(3):422-9.

11. Fabichak C, Silva-Júnior JS, Morrone LC. Síndrome de burnout em médicos residentes e preditores organizacionais do trabalho. Rev Bras Med Trab. 2014;12(2):79-84.

12. Coelho AT, Lorenzini LM, Reimão R, Rossini S,Suda EY. Qualidade de sono, depressão e ansiedade em universitários dos últimos semestres de cursos da área da saúde. Neurobiologia. 2010;73(1):35-9.

13. Martins LAN. Qualidade de vida dos médicos residentes: revisão de estudos brasileiros. Rev Bras Educ Med. 2010;6(1):12-8.

14. Chellappa SL, Araujo JF. O sono e os transtornos do sono na depressão. Rev Psiq Clin. 2007;34(6):285-9.

15. Müller MR, Guimarães SS. Impacto dos transtornos do sono sobre o funcionamento diário e a qualidade de vida. Estud Psicol. 2007;24(4):519-28.

16. Daley $M$, Morin CM, LeBlanc $M$, Grégoire JP, Savard J, Baillargeon L. Insomnia and its relationship to health-care utilization, work absenteeism, productivity and accidents. Sleep Med. 2009;10(4):427-38.

17. Savi MGM, Silva EL. O uso da informação e a prática clínica de médicos residentes. Perspect Ciênc Inf. 2011;16(3):232-54.

18. Ribeiro CRF, Silva YMGP, Oliveira SMC. O impacto da qualidade do sono na formação médica. Rev Soc Bras Clín Méd. 2014;12(1):8-14. 
19. Juliano ML. Importância da qualidade do sono em universitários e médicos residentes. Rev Neurocienc. 2013;21(3):331-2.

20. Moraes CAT, Edelmuth DGL, Novo NF, Hübner CVK. Qualidade de sono em estudantes de medicina do método de aprendizado baseado em problemas. Medicina (Ribeirão Preto). 2013;46(4):389-97.

21. Handel DA, Raja A, Lindsell CJ. The use of sleep aids among Emergency Medicine residents: a web based survey. BMC Health Serv Res. 2006;6:136.

22. Danda GJN, Ferreira GR, Azenha M, Souza KFR, Bastos O. Padrão do ciclo sono-vigília e sonolência excessiva diurna em estudantes de medicina. J Bras Psiquiatr. 2005;54(2):102-6.

23. Magalhães E, Oliveira ACMS, Govêia CS, Ladeira LCA, Queiroz DM, Vieira CV. Prevalência de síndrome de burnout entre os anestesiologistas do Distrito Federal. Rev Bras Anestesiol. 2015;65(2):104-10.

24. Silva LC, Maia LD, Pinheiro DR, Matias LSM, Salvo VF, André JO, et al. Correlação entre a exposição diária à luz azul violeta emitida por dispositivos digitais e a visão de adultos jovens. Saúde Rev. 2015;15(41):47-55.

Received in: 09/08/2016

Accepted for publication: 01/10/2016

Conflict of interest: none.

Source of funding: none.

\section{Mailing address:}

Kátia Sheylla Malta Purim

E-mail: kspurim@gmail.com / kspurim@gmail.com 